UDC 575+577.1: 633.1

\title{
Genetic variation of GLI-B1 locus in Ukrainian bread wheat varieties and lines
}

\author{
Yu. A. Popovych ${ }^{1}$, O. M. Blagodarova ${ }^{2}$, S. V. Chebotar ${ }^{1,2}$ \\ ${ }^{1}$ Odessa I. I. Mechnikov National University \\ 2, Dvoryanskaya Str., Odessa, Ukraine, 65082 \\ 2 Plant breeding and Genetics Institute, \\ National Centre of Seed and Cultivar Investigation of NAAS \\ Ovidiopol'skaya dor., 3, Odessa, Ukraine, 65036 \\ s.v.chebotar@onu.edu.ua
}

\begin{abstract}
Aim. To investigate polymorphism of Gli-Bl locus in modern Ukrainian bread wheat cultivars, to analyze the distribution of alleles and to compare the received data with the "core-collection of wheat cultivars" presented by Dr. E. Metakovsky. Methods. Eighty one bread wheat cultivars and lines from different plant breeding institutions and stations of Ukraine were tested using allele-specific primers to Gli-B1 locus developed by Zhang et al. [2003]. PCR products were fractionated in polyacrylamide gel (PAG) and then were stained by silver nitrate. Allelic variants of gliadins were analyzed by electrophoresis in acid polyacrylamide gel (APAGE). Results. Nine allelic variants of gliadins were revealed by APAGE and six alleles of Gli-B1 locus were detected by PCR-analysis. In $52 \%$ of modern Ukrainian bread wheat cultivars we revealed Gli-B1b allelic variant, according to PCR - Gli-B1.1 allele with a $369 \mathrm{bp}$ amplification fragment. In the genotypes of Ukrainian wheat cultivars, the 1RS.1BL translocation, which carries resistance genes, is frequent, as was detected by the absence of any amplification fragments with $G l i-B 1$ primers. The correspondence between allelic variants of gliadins and alleles of $G l i-B 1$ locus is discussed. Conclusions. DNA polymorphism of Gli-B1 locus examined in our research coincides with the diversity of allelic variants of gliadins, which were detected by APAGE method for Ukrainian bread wheat cultivar. However, PCR-analysis with applied primers carried out in this study does not distinguish the alleles that correspond to the Gli-B1c, Gli-B1g and Gli-B1e allelic variants of gliadins. The most common allele (52\%) for the investigated Ukrainian wheat varieties is Gli-B1.1 allele, which was characterized by the amplification fragment of $369 \mathrm{bp}$, and the presence of 1RS.1BL translocation, which corresponds to Gli-B1b and Gli-B11 allelic variants of gliadins obtained by APAGE, respectively.
\end{abstract}

Keyw or d s: Triticum aestivum L., Gli-B1, gliadins, polymorphism, PCR analysis.

(C) 2021 Yu. A. Popovych et al.; Published by the Institute of Molecular Biology and Genetics, NAS of Ukraine on behalf of Biopolymers and Cell. This is an Open Access article distributed under the terms of the Creative Commons Attribution License (http://creativecommons.org/licenses/by/4.0/), which permits unrestricted reuse, distribution, and reproduction in any medium, provided the original work is properly cited 


\section{Introduction}

Gliadins are large families of wheat storage proteins with similar amino acid sequences. Monomeric gliadin peptides are held together with glutenin polymers via intramolecular disulfide bonds and form gluten complex during mixing wheat grain flour and water [1]. It is considered that gliadins contribute to dough properties such as viscosity and extensibility, whereas glutenins affect strength and elasticity $[2,3]$. Moreover, gliadins contain CD epitopes, that can cause coeliac disease in $1-3 \%$ of population. Thus, studying the gliadins gene sequences will advance the development of low gluten wheat by using RNA interference or Crispr/Cas 9 technologies in order to create safe food for people with this disease [4-8].

Gliadins are classified as $\alpha-, \gamma-, \delta$ - and $\omega$-gliadins, based on their electrophoretic mobility and primary amino acid sequence $[9,10]$. The gliadin gene families are localized at six major loci on chromosomes of homoeologous group 1 and 6. Gli-A1, Gli-B1, Gli-D1 loci are coding $\gamma-, \delta$ - and $\omega$-gliadins, whereas Gli-A2, Gli-B2, Gli-D2 loci are coding $\alpha$-gliadins [10, 11]. Gli-1 loci have higher impact on flour quality than Gli-2, but major impact is provided by glutenins. Nonetheless, Gli-1 loci are linked to LMW glutenin genes $(G l u-3)$ and some important resistance genes, called $R$ genes $[11,13,15]$.

Each Gli locus encodes a group of gliadin polypeptides (allelic variant) inherited together as a simple Mendelian trait. There is a range of 40 to 150 copies of $\alpha$-genes in Gli-2 loci, 15-40 and 15-18 copies of $\gamma$ - and $\omega$-gliadin genes at Gli-1 loci respectively [14-16], de- pending on the wheat cultivar. A large number of pseudogenes have also been reported for each gene family, and some of them had very low expression level.

Multiple allelism of gliadins has been revealed by the acid polyacrylamide gel electrophoresis method $[17,18]$. Allelic variants differing from each other in a number of bands and their electrophoretic mobility are encoded by one Gli locus. 182 allelic variants for six main gliadin loci in more than 1000 common wheat cultivars have been described by Metakovsky et al. [18]. The most frequent allelic variants are Gli-B1b (28.2 \%) and Gli-D1b $(39.4 \%)$ [18].

Contribution of Gli-B1 locus to breadmaking quality is higher than that of Gli-Al and Gli-D1 loci [19]. Better quality is observed in cultivars with GLD 1B1 and GLD 1B2 (Gli$\mathrm{B} 1 \mathrm{~b}$ and Gli-B1d) allelic variants of gliadins. To date, 26 allelic variants of gliadins of Gli-B1 locus were described and cataloged [18].

Only one consensus sequence (MG560141.1) of Gli-B1 locus with length 6535908 bp was generated. Based on PacBio platform sequencing data, six $\gamma$-, one $\omega$ - and one $\delta$-gliadin active genes and eight pseudogenes were reported for Gli-B1 locus of Chinese Spring cultivar, which have Gli-B1a allelic variant $[18,20]$. To date, there are no full nucleotide sequences of $G l i-B 1$ locus of other wheat cultivars with different allelic variants of Gli-B1 locus. Based on AF234646 and M13712 sequences, allelespecific SNP markers (Gli-B1.1 and Gli-B1.2) for $\gamma$-gliadin pseudogene of $G l i-B 1$ locus were developed by Zhang et al. [21]. Amplification 
fragments lengths variation obtained with marker Gli-B1.2 in wheat varieties was observed due to the presence of microsatellite in the sequence, as reported by Devos et al. [22]. Polischuk et al. [23] applied PCR with the allele-specific primers for the analysis of six near-isogenic lines and 12 Ukrainian bread wheat cultivars and showed the correspondence between allelic variants of gliadins and Gli-B1 alleles. Also, the correspondence between PCR fragments length polymorphism (detected using primers developed by Zhang [21]) and allelic variants of gliadins at Gli-B1 locus had been reported for 46 common wheat cultivars in our previous studies [24]. In this research we aimed to explore polymorphism of Gli-Bl locus in modern Ukrainian bread wheat cultivars (most of which have been registered in The State Register of Plant Varieties Suitable for Dissemination in Ukraine after 2000 year), to analyze the distribution of alleles and to compare received data with "core-collection of wheat cultivars" presented by Dr. E. Metakovsky.

\section{Materials and Methods}

A set of 62 modern Ukrainian bread winter wheat cultivars and lines was received from different plant breeding institutes and stations as follows: The V. M. Remeslo Myronivka Institute of Wheat (MIW; 19 cultivars), Bila Tserkva Breeding Research Station (11 cultivars), The Institute of Irrigated Agriculture of the NAAS (10 cultivars), Poltava State Agrarian Academy (10 cultivars), Nosivska Selection and Research Station (3 cultivars and 5 lines), Donetsk Institute of Agricultural Production ( 2 cultivars), Driada Research and Production Company (1 cultivar), Luhansk
Institute of Breeding and Technologies (1 cultivar). Six near-isogenic lines (Gli-A1-1, Gli-B1-3, Gli-B1-4, Gli-B1-12, Gli-D1-4, Gli-D1-5) created by Dr. M. M. Kopus [25] and 13 reference wheat cultivars - Mironovskaya 808, Mironovskaya 61, Donskaya Polukarlikovaya, Albatros, Strumok, Suneca, Federation, Bezostaya 1, Escualo, Ardec, Caia, Prinqual, Krasnodonka (the reference cultivars from "core collection of common wheat", which have been collected by Dr. E. Metakovsky with the aim to represent the widest polymorphism of allelic variants of Gli-B1 locus), were used for comparison and verification of amplification fragments length.

For research we used five grains per variety. Each grain was divided into two parts. One half of the grain was used for analysis of allelic variants of gliadins by using electrophoresis according to F. O. Poperelya's method in acid polyacrylamide gel (APAGE) [26]. Gliadin allelic variants were identified using the catalogue of E. Metakovsky [18].

DNA was extracted from another half of grain by CTAB method [27]. PCR was performed with primers Gli-B1.1 (F: tgatctggccacaaaggga, R: cattggccaccaattcetgt) and Gli-B1.2 (F: tgatctggccacaaagggg, R: cattggccaccaattcctgt) developed by Zhang et al. [21]. A total volume of PCR reaction mixture was $10 \mu 1(1 \mu 1$ genomic DNA, $1 \mu 1$ DreamTaq buffer $(10 \mathrm{x}), 0.5 \mu 1 \mathrm{dNTP}(10 \mu \mathrm{M}), 5$ pmol each primer $(1 \mathrm{ng} / \mu \mathrm{l}), 0.25 \mathrm{U}$ DreamTaq DNA polymerase). Initial denaturation temperature was $95{ }^{\circ} \mathrm{C}$. The denaturation, annealing, and polymerization temperatures for 38 cycles were $95{ }^{\circ} \mathrm{C}, 56{ }^{\circ} \mathrm{C}$, and $72{ }^{\circ} \mathrm{C}$ respectively and final elongation $10 \mathrm{~min}, 72^{\circ} \mathrm{C}$. The electrophoresis of amplification products in the $7 \%$ polyacry- 
lamide gel stained with silver nitrate was used to visualize amplification fragments [28]. The length of amplification fragments was calculated using GelAnalyser software.

Allele frequency was calculated considering heterogeneous cultivars [29]. Nei's genetic variation index [30] was calculated according to the formula

$$
\mathrm{H}=1-\sum p_{i}^{2}
$$

where $p_{i}$ is the frequency of the certain allele at the locus.

\section{Results and Discussion}

Nine allelic variants of gliadins were revealed among 62 Ukrainian bread wheat cultivars and 6 wheat lines created by M. M. Kopus tested by acid polyacrylamide electrophoresis. The most frequent allelic variant was Gli-B1b $(\mathrm{p}=0.52$ ) found in 35 cultivars (Table 1). GliB11 allelic variant $(p=0.32)$ was found in 21 cultivars. Genotypes with this allelic variant have 1RS.1BL wheat-rye translocation, which carries resistance genes $\mathrm{Pm} 8, \mathrm{Sr} 31, \mathrm{Lr} 26, \mathrm{Yr} 9$, and reduces bread-making quality. Other allelic variants Gli-B1e $(\mathrm{p}=0.045)$, Gli-B1d $(p=0.03)$, Gli-B1f $(p=0.03)$, Gli-B1c $(p=0.015)$, Gli-B1h $(\mathrm{p}=0.015)$, Gli-B1o $(\mathrm{p}=0.015)$, Gli$B 1 \mathrm{~g}(\mathrm{p}=0.015)$ were rare and found in two or one cultivars. Nei`s genetic variation index was $\mathrm{H}=0.61$.

Based on PCR analysis all cultivars were divided into six groups. The first and the second groups included wheat cultivars with Gli-B1.1 allele, the third group combined cultivars that did not have any amplification fragments, and other three groups were characterized by Gli-B1.2 allele.
The first group was the largest and included cultivars Vyshyvanka, MIP Assol, Oberih Myronivsky, Mariia, Sonata and other with the amplification fragment of $369 \mathrm{bp}$ in Gli-B1.1 locus. The same size amplification products were identified in cv. Bezostaya 1, Mironovskaya 808 and Albatros (Fig. 1). This group included 36 wheat cultivars and lines with Gli-B1b allelic variant of gliadins (Table 1).

Only one wheat line Gli-B1-12 belonged to the second group. In PCR with allele-specific primers line Gli-B1-12 produced a $400 \mathrm{bp}$ amplification fragment of Gli-B1.1 allele as in variety Federation (Fig. 1). Both cultivar and line were characterized by Gli-B1o allelic variant.

The third group included 21 wheat cultivars that did not produce in PCR any amplification fragments (null allele) due to the 1RS.1BL wheat-rye translocation (cultivar Ledia, Fig. 1, Fig. 2). All cultivars in the group had Gli-B11 allelic variant as expected (Table 1).

Seven wheat cultivars and lines that produced a $397 \mathrm{bp}$ amplification fragment of Gli-B1.2 allele as in reference varieties Escualo and Prinqual, were assigned to the fourth group

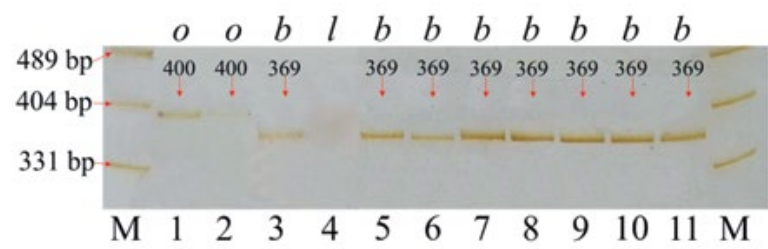

Fig. 1. Electrophoregram of amplification fragments produced by PCR with allele-specific primers to Gli-B1.1 allele and DNA of wheat cultivars: 1 - Gli-B1-12; 2 Federation; 3 - Vyshyvanka; 4 - Ledia; 5 - Bezostaya 1;6-Mironovskaya 808; 7 - Anatoliia; 8-MIP Assol; 9 - Oberih Myronivsky; 10 - Mariia; 11 - Sonata; $M$ - molecular weight marker pUC 19/Msp I. 


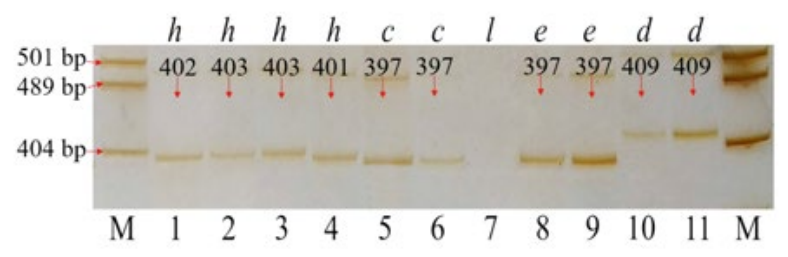

Fig. 2. Electrophoregram of amplification fragments produced by PCR with allele-specific primers to Gli-B1.2 allele and DNA of wheat cultivars: 1 -Ardec; 2 - Caia; 3 - Madiarka; 4 - Krasnodonka; 5 - Prinqual; 6 L 59/95; 7 - Ledia; 8 - Escualo; 9 - Liutenka; 10 Suneca; $11-$ KS 22-04; $M$ - molecular weight marker pUC 19/Msp I.

(Fig. 2). Four different allelic variants were revealed among cultivars in this group. Gli-B1e allelic variant was determined in Hovtva, Schedra Nyva, Liutenka cultivars, Gli-B1f allelic variant was found in Myronivska Slava, Zymoiarka varieties, Gli-B1g and Gli-B1c allelic variants were determined in Gli-B1-4 and L 59/95 wheat lines, respectively (Table 1).
Only one cultivar belonged to the fifth group which was distinguished by Gli-B1.2 allele with the amplification fragment of 403 bp. The reference cultivars - Ardec (402 bp), Caia (403 bp) and Krasnodonka (401 bp) were used to identify amplification fragment length of cultivar Madiarka (Fig. 2). All the above varieties have Gli-B1h allelic variant (Table 1).

The sixth group was distinguished by Gli-B1.2 allele with the amplification fragment of $409 \mathrm{bp}$. We revealed this amplification fragment for the cv. Bilotserkivska Napivkarlykova and line KS 22-04 as in reference cv. Donskaya Polykarlikovaya and Suneca (Fig. 2). Gli-B1d allelic variant of gliadins, which is predominant in Mexico, Canada and Krasnodar (Russia) [18], was detected for all cultivars in this group. Due to the controversial results with Polischuk et al. [23], who had pointed out that Gli-B1.1 allele corresponds to Gli-B1d allelic variant, cultivar Strumok was used to

Table 1. Polymorphism of Gli-B1 locus revealed by APAGE and allele-specific PCR

\begin{tabular}{|c|l|c|c|c|}
\hline \multirow{2}{*}{ № } & \multirow{2}{*}{$\begin{array}{c}\text { Cultivar (Year } \\
\text { of registration) }\end{array}$} & \multicolumn{2}{|c|}{$\begin{array}{c}\text { Allele revealed by } \\
\text { PCR }\end{array}$} & $\begin{array}{c}\text { Allelic variant } \\
\text { of gliadin } \\
\text { (APAGE) }\end{array}$ \\
\cline { 3 - 4 } & \multicolumn{1}{|c|}{ Gli-B1.1 } & Gli-B1.2 & b \\
\hline 2 & Albatros (1990) & 369 & - & $\mathrm{b}$ \\
\hline 3 & Anatoliia (2015) & 369 & - & $\mathrm{b}$ \\
\hline 4 & Balada Myronivska & 369 & - & $\mathrm{b}$ \\
\hline 5 & Bilosnizhka (2006) & 369 & - & $\mathrm{b}$ \\
\hline 6 & Blagho (2011) & 369 & - & $\mathrm{b}$ \\
\hline 7 & Burghunka (2015) & 369 & - & $\mathrm{b}$ \\
\hline 8 & Donetska 48 & 369 & - & $\mathrm{b}$ \\
\hline 9 & Gli-A1-1 & 369 & - & $\mathrm{b}$ \\
\hline 10 & Gli-D1-4 & 369 & - & $\mathrm{b}$ \\
\hline 11 & Gli-D1-5 & 369 & - & $\mathrm{b}$ \\
\hline 12 & $\begin{array}{l}\text { Hratsiia Myronivska } \\
(2018)\end{array}$ & 369 & - & $\mathrm{b}$ \\
\hline
\end{tabular}

\begin{tabular}{|c|l|c|c|c|}
\hline \multirow{2}{*}{ № } & \multirow{2}{*}{$\begin{array}{c}\text { Cultivar (Year } \\
\text { of registration) }\end{array}$} & \multicolumn{2}{|c|}{$\begin{array}{c}\text { Allele revealed by } \\
\text { PCR }\end{array}$} & $\begin{array}{c}\text { Allelic variant } \\
\text { of gliadin } \\
\text { (APAGE) }\end{array}$ \\
\cline { 3 - 4 } 13 & $\begin{array}{l}\text { Khaersonska Bezosta } \\
\text { (2002) }\end{array}$ & 369 & - & b \\
\hline 14 & Klarisa (2014) & 369 & - & b \\
\hline 15 & Kokhana (2009) & 369 & - & $\mathrm{b}$ \\
\hline 16 & Konka (2014) & 369 & - & $\mathrm{b}$ \\
\hline 17 & Koshova (2017) & 369 & - & $\mathrm{b}$ \\
\hline 18 & Levada (2005) & 369 & - & $\mathrm{b}$ \\
\hline 19 & Lisova Pisnia (2008) & $369+$ & - & $\mathrm{b}+1$ \\
\hline 20 & Mariia (2013) & 369 & - & $\mathrm{b}$ \\
\hline 21 & Metalist (2014) & 369 & - & $\mathrm{b}$ \\
\hline 22 & MIP Assol (2018) & 369 & - & $\mathrm{b}$ \\
\hline 23 & $\begin{array}{l}\text { MIP Podolianka } \\
\text { (2003) }\end{array}$ & 369 & - & $\mathrm{b}$ \\
\hline
\end{tabular}


Yu. A. Popovych, O. M. Blagodarova, S. V. Chebotar

\begin{tabular}{|c|c|c|c|c|}
\hline \multirow[t]{2}{*}{ № } & \multirow{2}{*}{$\begin{array}{l}\text { Cultivar (Year } \\
\text { of registration) }\end{array}$} & \multicolumn{2}{|c|}{$\begin{array}{c}\text { Allele revealed by } \\
\text { PCR }\end{array}$} & \multirow{2}{*}{$\begin{array}{c}\text { Allelic variant } \\
\text { of gliadin } \\
\text { (APAGE) }\end{array}$} \\
\hline & & Gli-B1.1 & Gli-B1.2 & \\
\hline 24 & $\begin{array}{l}\text { MIP Vyshyvanka } \\
(2017)\end{array}$ & 369 & - & $\mathrm{b}$ \\
\hline 25 & $\begin{array}{l}\text { Mironovskaya } 808 \\
(1967)\end{array}$ & 369 & - & $\mathrm{b}$ \\
\hline 26 & $\begin{array}{l}\text { Oberih Myronivsky } \\
(2014)\end{array}$ & 369 & - & $\mathrm{b}$ \\
\hline 27 & Orzhytsia (2013) & 369 & - & $\mathrm{b}$ \\
\hline 28 & Ovidii (2009) & 369 & - & $\mathrm{b}$ \\
\hline 29 & Pamiati Remesla (2009) & 369 & - & $\mathrm{b}$ \\
\hline 30 & Romantyka (2009) & 369 & - & $\mathrm{b}$ \\
\hline 31 & Sahaidak (2010) & 369 & - & $\mathrm{b}$ \\
\hline 32 & Sonata & 369 & - & $\mathrm{b}$ \\
\hline 33 & Sydor Kovpak & 369 & - & $\mathrm{b}$ \\
\hline 34 & Tsarivna (2008) & 369 & - & $\mathrm{b}$ \\
\hline 35 & Tsarychanka (2013) & 369 & - & $\mathrm{b}$ \\
\hline 36 & Ukrainka Poltavska & 369 & - & $\mathrm{b}$ \\
\hline 37 & $\begin{array}{l}\text { Vezha Myronivska } \\
(2018)\end{array}$ & 369 & - & $\mathrm{b}$ \\
\hline 38 & Vidrada (2010) & 369 & - & $\mathrm{b}$ \\
\hline 39 & Yasochka (2006) & 369 & - & $\mathrm{b}$ \\
\hline 40 & Gli-B1-12 & 400 & - & $\mathrm{o}$ \\
\hline 41 & Federation & 400 & - & o \\
\hline 42 & $\begin{array}{l}\text { Bilotserkivska Napiv- } \\
\text { karlykova (1999) }\end{array}$ & - & 409 & $d$ \\
\hline 43 & $\begin{array}{l}\text { Donskaya Polykar- } \\
\text { likovaya (1985) }\end{array}$ & - & 409 & $d$ \\
\hline 44 & KS 22-04 (2004) & - & 409 & $\mathrm{~d}$ \\
\hline 45 & Strumok (1998) & - & 409 & $\mathrm{~d}$ \\
\hline 46 & Suneca & - & 409 & $\mathrm{~d}$ \\
\hline 47 & Ardec & - & 402 & $\mathrm{~h}$ \\
\hline 48 & Caia & - & 403 & $\mathrm{~h}$ \\
\hline 49 & Krasnodonka & - & 401 & $\mathrm{~h}$ \\
\hline 50 & Madiarka (2008) & - & 403 & $\mathrm{~h} ?$ \\
\hline 51 & Hovtva & - & 397 & $\mathrm{e}$ \\
\hline 52 & Liutenka & - & 397 & $\mathrm{e}$ \\
\hline 53 & Shchedra Nyva (2011) & - & 397 & $\mathrm{e}$ \\
\hline 54 & Escualo & - & 397 & $\mathrm{e}$ \\
\hline 55 & L59-95 (1995) & - & 397 & $\mathrm{c}$ \\
\hline
\end{tabular}

\begin{tabular}{|c|c|c|c|c|}
\hline \multirow[t]{2}{*}{ № } & \multirow{2}{*}{$\begin{array}{l}\text { Cultivar (Year } \\
\text { of registration) }\end{array}$} & \multicolumn{2}{|c|}{$\begin{array}{c}\text { Allele revealed by } \\
\text { PCR }\end{array}$} & \multirow{2}{*}{$\begin{array}{c}\text { Allelic variant } \\
\text { of gliadin } \\
\text { (APAGE) }\end{array}$} \\
\hline & & Gli-B1.1 & Gli-B1.2 & \\
\hline 56 & Prinqual & - & 397 & $\mathrm{c}$ \\
\hline 57 & Gli-B1-4 & - & 397 & $\mathrm{~g}$ \\
\hline 58 & $\begin{array}{l}\text { Myronivska Slava } \\
(2017)\end{array}$ & - & 397 & $\mathrm{f} ?$ \\
\hline 59 & Zymoiarka (2007) & - & 397 & f? \\
\hline 60 & Ariivka (2017) & - & - & 1 \\
\hline 61 & $\begin{array}{l}\text { Charodiika Bilot- } \\
\text { serkivska (2011) }\end{array}$ & - & - & 1 \\
\hline 62 & $\begin{array}{l}\text { Estafeta Myronivska } \\
(2018)\end{array}$ & - & - & 1 \\
\hline 63 & KS 1 (1995) & - & - & 1 \\
\hline 64 & KS 14 (2005) & - & - & 1 \\
\hline 65 & Kryzhynka (2002) & - & - & 1 \\
\hline 66 & L 41/95 (1995) & - & - & 1 \\
\hline 67 & Ledia (2016) & - & - & 1 \\
\hline 68 & Lybid' (2006) & - & - & 1 \\
\hline 69 & MIP Dniprianka (2018) & - & - & 1 \\
\hline 70 & $\begin{array}{l}\text { Myronivska } \\
\text { Zolotoverkha }\end{array}$ & - & - & 1 \\
\hline 71 & Myronivska 61 (1987) & - & - & 1 \\
\hline 72 & Myronivska 65 (2000) & - & - & 1 \\
\hline 73 & $\begin{array}{l}\text { Perlyna Lisostepu } \\
(2001)\end{array}$ & - & - & 1 \\
\hline 74 & $\begin{array}{l}\text { Svitanok } \\
\text { Myronivsky (2014) }\end{array}$ & - & - & 1 \\
\hline 75 & $\begin{array}{l}\text { Trudivnytsa } \\
\text { Myronivska (2017) }\end{array}$ & - & - & 1 \\
\hline 76 & $\begin{array}{l}\text { Yuviliar Myronivsky } \\
(2009)\end{array}$ & - & - & 1 \\
\hline 77 & Yuvivata $60(2013)$ & - & - & 1 \\
\hline 78 & Vilshana (2010) & - & - & 1 \\
\hline 79 & $\begin{array}{l}\text { Vodohrai Bilot- } \\
\text { serkivsky (2014) }\end{array}$ & - & - & 1 \\
\hline 80 & $\begin{array}{l}\text { Zoriana Nosivska } \\
\text { (1998) }\end{array}$ & - & - & 1 \\
\hline 81 & Gli-B1-3 & - & - & 1 \\
\hline
\end{tabular}

*Reference cultivars are highlighted in bold. The year of registration in The State Register of Plant Varieties Suitable for Dissemination in Ukraine is indicated in parentheses. 
check this. As the result of PCR for Strumok variety, we received Gli-B1.2 allele with amplification fragment of $409 \mathrm{bp}$ (Table 1).

The results obtained in our research demonstrated wide distribution of two main alleles of Gli-B1 locus among modern Ukrainian wheat cultivars. The first allele is Gli-B1.1 with the amplification fragment of $369 \mathrm{bp}$, according to PCR, which corresponds to Gli-B1b allelic variant of gliadins that has positive impact on dough quality and is present in the majority of bread wheat cultivars in Ukraine and some other countries, such as Bulgaria, Romania and Russia [18]. The second allele is null allele in PCR with allele-specific primers, which corresponds to Gli-B11 allelic variant, linked to some important resistance genes. This allelic variant was predominant in sets of cultivars from The V. M. Remeslo Myronivka Institute of Wheat $(\mathrm{MIW})(\mathrm{p}=0.474)$ and Nosivska Selection and Breeding station $(\mathrm{p}=0.75)$. According to Kozub et al. [29], Gli-B11 became the most frequent $(\mathrm{p}=0.439)$ in a set of ForestSteppe wheat cultivars developed in 1996-2007 in MIW and is the most frequent $(\mathrm{p}=0.452)$ in wheat cultivars of MIW created after 2010 [31].

Among Ukrainian breeding centers the highest diversity of Gli-B1 alleles was revealed in The V. M. Remeslo Myronivka Institute of Wheat (4 allelic variants/19 cultivars) with genetic diversity $\mathrm{H}=0.57$ and Bila Tserkva Breeding Research Station (4 allelic variants/11 cultivars) with genetic variation $\mathrm{H}=0.6$. The Rare for Ukraine allelic variants were introduced by Poltava State Agrarian Academy (Gli-B1e), Nosivska Selection and Research Station (Gli-B1c, Gli-B1d), The V. M. Remeslo Myronivka Institute of Wheat (Gli-B1h, Gli-B1f) and Bila Tserkva Breeding
Research Station (Gli-B1d, Gli-B1e). The allelic variants Gli-B1c, Gli-B1g and Gli-B1o were present only in wheat lines.

Gli-B1 loci carry not only important storage protein genes, but also are linked with the resistance and adaptation genes that provide the predominance of certain alleles in the specific environment.

\section{Conclusions}

DNA polymorphism of Gli-B1 locus examined in our research coincided with the diversity of allelic variants of gliadins, which were detected by APAGE method in Ukrainian bread wheat cultivars, and divided all cultivars into six groups at the DNA level.

The predominant $(\mathrm{p}=0.52)$ allele of $G l i-B 1$ locus revealed by PCR was Gli-B1.1 with the amplification fragment length of $369 \mathrm{bp}$, also frequent allele $(p=0.32)$ was null allele (1RS.1BL translocation). Thereby the predominant allelic variants of gliadins in modern Ukrainian wheat varieties were Gli-B1b and Gli-B11 that corresponds to earlier studies [29, 31-33]. Gli-B1.2 allele occurs much less often than Gli-B1.1 and we revealed three types of different by length amplification fragments with primers specific to Gli-B1.2.

Clear correspondence observed in this study allows one to distinguish some important allelic variants of gliadins such as Gli-B1b, GliB11, Gli-B1d, Gli-B1h by the PCR method. However, DNA-analysis applied in this study does not distinguish the Gli-B1c, Gli-B1g and Gli-B1e allelic variants. Nevertheless, at the same time using PCR with Gli-B1.2 allelespecific primers we revealed polymorphism at Gli-B1 locus among the cultivars with Gli-B1h allelic variant of gliadins. 
The correspondence between allelic variants of gliadins and alleles of Gli-B1 locus in Ukrainian bread wheat cultivars is retained as in the previously studied [24] "core collection of wheat cultivars".

\section{Acknowledgments}

The authors are grateful for the provided material for research to National Center for Plant Genetic Resources of Ukraine and personally Academician Yu.Lavrenenko, Dr. E. Metakovsky, I. Sozinov, Dr. V. Moskalets.

\section{REFERENCES}

1. Urade R, Sato N, Sugiyama M. Gliadins from wheat grain: an overview, from primary structure to nanostructures of aggregates. Biophys Rev. 2018; 10:435-43.

2. Gianibelli MC, Larroque OR, MacRitchie F, Wrigley $C W$. Biochemical, genetic, and molecular characterization of wheat glutenin and its component subunits. Cereal Chem. 2001; 78(6):635-46.

3. Wieser $\mathrm{H}$. Chemistry of gluten proteins. Food Microbiol. 2007; 24(2):115-9.

4. Vriezinga SL, Schweizer JJ, Koning F, Mearin ML. Coeliac disease and glutenrelated disorders in childhood. Nat Rev Gastroenterol Hepatol. 2015; 12:527-36.

5. Catassi C, Fasano A. Coeliac disease: The debate on coeliac disease screening - are we there yet? Nat Rev Gastroenterol Hepatol. 2014; 11:457-8.

6. Wang DW, Li D, Wang J, Zhao Y, Wang Zh, Yue GLX, Huanju Q, Zhang K, Dong L, Wang D. Genomewide analysis of complex wheat gliadins, the dominant carriers of celiac disease epitopes. Sci Rep. 2017; 7:44609.

7. Jouanin A, Schaart JG, Boyd LA, et al. Outlook for coeliac disease patients: towards bread wheat with hypoimmunogenic gluten by gene editing of $\alpha$ - and $\gamma$-gliadin gene families. BMC Plant Biol. 2019; 19: 333.

8. Li D, Jin H, Zhang $K$, Wang Zh, Wang F, Zhao Y, Huo N, Liu X, Gu Y, Wang D, Dong L. Analysis of the Gli-D2 locus identifies a genetic target for simultaneously improving the breadmaking and health-related traits of com-mon wheat. Plant J. 2018; 95(3):414-426.

9. Wrigley $C W$, Shepherd $K W$. Electrofocusing of grain proteins from wheat genotypes. Ann NY Acad Sci. 1973; 209(1):154-62.

10. Anderson $O D$, Dong L, Huo N, Gu, YQ. A new class of wheat gliadin genes and proteins. PLoS One. 2012; 7:e52139

11. Payne PI, Holt LM, Lawrence GJ, Law CN. The genetics of gliadin and glutenin, the major storage proteins of the wheat endosperm. Plant Food Hum Nutr. 1982; 31:229-41.

12. Hafeez AN, Arora S, Ghosh S, Gilbert D, Bowden RL, Wulff $B H$. Creation and judicious application of a wheat resistance genes atlas. Mol Plant. 2021; 14(7): 1053-70.

13. Huang L, Brooks SA, Li W, Fellers JP, Trick HN, Gill BS. Map-based cloning of leaf rust resistance gene Lr21 from the large and polyploid genome of bread wheat. Genetics. 2003; 164(2): 655-64.

14. Anderson $O D$, Greene $F C$. The $\alpha$-gliadin gene family. II DNA and protein sequence variation, subfamily structure, and origins of pseudogenes. Theor Appl Genet. 1997; 95: 59-65.

15. Okita TW, Cheesbrough V, Reeves $C D$. Evolution and heterogeneity of the $\alpha$-/ $\beta$-type and $\gamma$-type gliadin DNA sequences. J Biol Chem. 1985; 260(13):8203-13.

16. Hsia $C C$, Anderson $O D$. Isolation and characterization of wheat gliadin genes. Theor Appl Genet. 2001; 103: 37-44.

17. Sozinov AA, Poperelya FA. Genetic classification of prolamins and its use for plant breeding. Ann Technol Agric. 1980; 29(2):229-45.

18. Metakovsky E, Melnik VA, Rodriguez-Quijano M, Upelniek VP, Carrillo JM. A catalog of glidin alleles: Poly-morphism of 20th-century common wheat germplasm. Crop J. 2018; 6(6):629-41.

19. Sozinov AA, Poperelya FA. Prolamin polymorphism and breeding. Visn sel-khozh nayki. 1979; 10:21-34.

20. Huo N, Zhang S, Zhu T, Dong L, Wang Y, Mohr T, Hu T, Liu Z, Dvorak J, Luo MC, Wang D, Lee JY, Altenbach $S$, Gu $Y Q$. Gene duplication and evolution dynamics in the homeologous regions harboring multiple prolamin and resistance gene families in hexaploid wheat. Front Plant Sci. 2018; 9:673. 
21. Zhang, Gianibelli M, Rampling ML, Gale KR. Identification of SNPs and development of allele-specific PCR markers for $\gamma$-gliadin alleles in Triticum aestivum. Theor Appl Genet. 2003; 107: 130-8.

22. Devos KM, Bryan GJ, Collins AJ, Stephenson P, Gale $M D$. Application of two microsatellite sequences in wheat storage proteins as molecular markers. Theor Appl Genet. 1995; 90:247-52.

23. Polischuk AM, Chebotar SV, Blagodarova OM, Kozub NA, Sozinov IA, Sivolap YuM. Analysis of varieties and near-isogenic lines of bread wheat by PCR with allele-specific primers to Gli-1 and Glu-3 loci. Cytol Genet. 2010; 44:345-53.

24. Popovych Y, Chebotar S, Melnik V, RodriguezQuijano M, Pascual L, Rogers WJ, Metakovsky E. Congruity of the polymorphisms in the expressed and noncoding parts of the Gli-B1 locus in common wheat. Agronomy. 2020; 10(10):1510.

25. Copus MM. About the natural gene geography of gliadin alleles in winter bread wheat. Selektsya \& semenovodstvo. 1994; 5:9-14.

26. Poperelya FA. Gliadin polymorphism and its association with grain quality, productivity and adaptation properties of winter bread wheat varieties. Breeding, seed production and intensive technology of wheat cultivation. Moscow: Agropromizdat. 1989:138-50.

27. Doyle JJ, Doyle JL. Isolation of plant DNA from fresh tissue. Focus. 1990; 12:13-15.

28. Promega Technical Manual. Gene Print. STR Systems. Printed in USA. Revised. 1999; 7:52.

29. Kozub NA, Sozinov IA, Sobko TA, Kolyuchii VT, Kuptsov SV, Sozinov AA. Variation at storage protein loci in winter common wheat cultivars of the central forest-steppe of Ukraine. Cytol Genet. 2009; 43:55-62.

30. Nei M. Analysis of gene diversity in subdivided populations. Proc Natl Acad Sci USA. 1973; 70(12): 3321-3.

31. Kozub NO, Sozinov IO, Chaika VM, Sozinova OI, Janse LA, Blume YaB. Changes in allele frequencies at storage protein loci of winter common wheat under climate change. Cytol Genet. 2020; 54:305-17.

32. Blagodarova OM, Lytvynenko MA, Golub YeA. Gene geography of alleles at gliadin- and glutenin-coding loci of Ukrainian winter common wheat varieties and their association with agronomical traits. Coll Sci Pap Inst Breed Genet. 2004; 46(6):124-38.

33. Kozub NA, Sozinov IA, Karelov AV, Blume YaB, Sozinov $A A$. Diversity of Ukrainian winter common wheat varieties with respect to storage protein loci and molecular markers for disease resistance genes. Cytol Genet. 2017; 51:117-129.

\section{Генетична різноманітність $G L I-B 1$ локусу в українських сортах та лініях пшениці м'якої}

\section{Ю. А. Попович, О. М. Благодарова, С. В. Чеботар}

Мета. Дослідити поліморфізм Gli-B1 локусу в українських сортах та лініях пшениці м'якої, проаналізувати поширення виявлених алелів та порівняти отримані дані із «кор-колекцією сортів пшениці», що була надана Д-р. Є. Метаковським Методи. Вісімдесят один сорт та лінія пшениці м'якої з різних селекційно-генетичних центрів України аналізували за допомогою ПЛР з алельспецифічними праймерами до Gli-B1 локусу, розробленими Zhang et al. [2003]. Продукти ПЛР фракціонували у поліакриламідному гелі, після чого фарбували 3 використанням аргентум нітрату. Алельні варіанти гліадинів аналізували методом електрофорезу в кислому поліакриламідному гелі (кПААГ). Результати. Дев'ять алельних варіантів гліадинів було виявлено методом електрофорезу в кислому ПААГ та шість алелів Gli-B1 локусу знайдено за допомогою ПЛРаналізу. У 52 \% сортів зустрічався алель Gli-B1b, що характеризувався Gli-B1.1 алелем із довжиною фрагменту ампліфікації 369 п.н. 1RS.1BL транслокація, що несе гени стійкості, також часто зустрічалася в українських сортах пшениці м'якої. Відповідність між алельними варіантами гліадинів та алелями Gli-B1 локусу обговорюється. Висновки. ДНК-поліморфізм Gli-B1 локусу, виявлений у дослідженні за допомогою ПЛР, логічно збігається з поліморфізмом, що визначається за алельними варіантами гліадинів, проте ПЛР-аналіз iз застосованими у роботі праймерами, не дозволив розрізнити алелі, що відповідають Gli-B1c, Gli-B1g та Gli-B1e алельним варіантам гліадинів. Найбільш поширеним для дослідженої вибірки українських сортів пшениці м'якої є алель Gli-B1.1, що детектується фрагментом апліфікації 369 п.н. та 1RS.1BL транслокація, яка не дає жодних фрагменів ампліфікації із праймера- 
ми до Gli-Bl, що відповідає алельним варіантам гліадинів Gli-B1b та Gli-B11, відповідно.

Кл юч о в і сл ов а: Triticum aestivum L., Gli-B1, гліадини, поліморфізм, ПЛР-аналіз.

\section{Генетическое разнообразие по $G L I-B 1$ локусу в украинских сортах и линиях пшеницы мягкой}

Ю. А. Попович, Е. М. Благодарова, С. В. Чеботарь

Цель. Исследовать полиморфизм по Gli-B1 локусу в современных украинских сортах пшеницы мягкой, проанализировать частоты встречаемости аллелей и сравнить полученные данные с «кор-коллекцией сортов пшеницы» предоставленной Др. Е. Метаковским. Методы. Восемьдесят один сорт и линия пшеницы мягкой из разных селекционно-генетических центров и институтов Украины анализировали с помощью аллель-специфических праймеров разработанных Zhang et al. [2003]. Продукты ПЦР фракционировали в полиакриламидном геле и окрашивали с использованием нитрата серебра. Аллельные варианты глиадинов анализировали 3 помощью электрофореза в кислом полиакриламидном геле (кПААГ). Результаты. Было выявлено девять аллельных вариантов глиадинов и шесть аллелей Gli-B1 локуса методом ПЦР. У 52 \% украинских сортов пшеницы в исследуемой выборке был выявлен Gli-Blb аллель- ный вариант глиадинов, который характеризовался Gli-B1.1 аллелем при ПЦР тестировании (фрагмент амплификации 369 п.н.). 1RS.1BL транслокация, что несет гены устойчивости, также часто встречалась в исследованных сортах пшеницы. В статье обсуждается соответствие между аллельными вариантами глиадинов и аллелями Gli-B1 локуса, выявленными с помощью ПЦР. Выводы. ДНК-полиморфизм выявленный по Gli-B1 локусу в исследуемых сортах пшеницы, логично соотносится с полиморфизмом аллельных вариантов глиадинов, но ПЦР-анализ с использованными в работе праймерами, не позволил дифференцировать аллели соответствующие Gli-B1c, Gli-B1g та Gli-B1e аллельным вариантам глиадинових белков. Наиболее рапостраненными аллелями в исследованой выборке украинских сортов пшеницы является аллель Gli-B1.1, который детектируется фрагментом амплификации 369 п.н., и 1RS.1BL транслокация, при наличии которой фрагментов амплификации с праймерами к Gli-B1 не выявляется, что соответствует аллельным вариантам глиадинов Gli-B1b и Gli-B11, соответственно.

Ключевые слова: Triticum aestivum L., Gli-B1, глиадины, полиморфизм, ПЦР-анализ ,

Received 25.07.2021 